\begin{tabular}{|c|c|c|}
\hline$ב$ & International Journal of Current Research in & \\
\hline $\begin{array}{l}\text { EXCELLENT } \\
\text { PUBLISHERS }\end{array}$ & $\begin{array}{c}\text { Biosciences and Plant Biology } \\
\text { ISSN: 2349-8080 (Online) • Volume } 3 \text { • Number } 5 \text { (May-2016) } \\
\text { Journal homepage: } \text { www.ijcrbp.com }\end{array}$ & 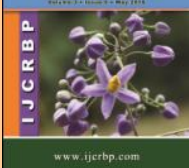 \\
\hline
\end{tabular}

\title{
An Overview of Medicinally Important Phyto Resources Used by the Manipuri Community of North Tripura District of Tripura, North East India
}

\author{
H. Reshmi Singha ${ }^{1}$, Kripamoy Chakraborty ${ }^{1}$ and Abhijit Datta ${ }^{2 *}$ \\ ${ }^{1}$ Department of Botany, Tripura University, Suryamaninagar-799 022, Tripura, India \\ ${ }^{2}$ Department of Botany, Government Degree College Dharmanagar, Dharmanagar-799 253, Tripura, India \\ *Corresponding author.
}

\begin{abstract}
A b stract
An ethno-medicinal investigation was conducted for the documentation of the traditional knowledge of medicinal plants being used by the Manipuri community of north Tripura district. This present investigation provides valuable information about the different uses of plants in their primary health care system. The information had been documented by interviewing their own medicine man called Maiba or Maibi following different ethnobotanical methods. We have documented 43 plants species belonging to 35 families used for treating 42 human ailments. Among the medicinal plants reported, the most common growth form was herbs $(55.81 \%)$ followed by trees $(30.99 \%)$ and shrubs (13.95\%). Leaves were the most frequently used plant parts. The high degree of consensus among the informants suggests that existing use and knowledge are still strong, and thus the preservation of indigenous knowledge would show good prudence in acting before much has been lost. This study also provides a better database for future studies.
\end{abstract}

\section{Article Info}

Accepted: 07 April 2016

Available Online: 06 May 2016

Keywords

Ailment

Ethno-medicine

Indigenous knowledge

Manipuri community

\section{Introduction}

Starvation and ailment are the two most important phenomena which threaten the survival of human beings since primeval time. Human beings have tried various methods and strategies to cure themselves from several diseases. Due to the unproblematic access to the number of plants of medicinal interest growing around the dwelling place, the initial empirical attempts were made with plants and plant products. In spite of tremendous advances in synthetic drugs and medicine, a large number of people still believe on herbal drugs with hope of safety and efficacy (Sandberg et al., 2001; Peter, 2004; Salim et al., 2008). The survey conducted by World Health Organization (WHO), revealed the fact that as many as $80 \%$ of the world's people depend on traditional medicine for their primary healthcare need (Azaizeh et al., 2003) due to the considerable economic benefits in the development of indigenous medicines and in the use of medicinal plants for the treatment of several diseases. A variety of higher plants are well known for drug therapy in conventional medicine (Martini-Bettolo, 1980; Farnsworth et al., 1985; Akerele, 1993; Aniyam, 1995; Martin, 1995a, 1995b; Ghorebani et al., 2006; Shanmugasundaram et al., 2011).

The use of phyto resources as a remedy of various diseases was practiced by our ancestors, a process which must have started by trial and error (Umapriya et al., 2010) but with the dawn of modern civilization such traditional knowledge about medicinal plants are transmitted very inadequately from one generation to 
other or transmitted in less significant fractions (Kuhnlein and Receveur, 1996; Sheng-Ji, 2001). The valuable knowledge is therefore remain as an unwritten form and requires burning measures of conservation and documentation. However, several ethno-medicinal surveys were conducted in Tripura by different researchers (Shil and Dutta Choudhury, 2009; Singh et al., 1997; Majumdar et al., 2006; Majumdar et al., 2007; Das et al., 2009; Das and Dutta Choudhury, 2010; Roy, 2010; Sen et al., 2011; Das and Dutta Choudhury, 2012; Das et al., 2014; Sharma et al., 2014). But no survey was conducted among the people of Manipuri community of north Tripura district. Therefore, current ethnobotanical survey was conducted for investigating and documenting the traditional usages of different plant resources by Manipuri community for their healthcare system.

\section{Materials and methods}

\section{Study area}

Tripura, the third smallest state of India occupying an area of about $10,491.69$ kilometer $^{2}$ ( $22^{\circ} 56 \mathrm{~N}^{\prime}$ to $24^{\circ} 32 \mathrm{~N}^{\prime}$ and $91^{\circ} 09^{\prime} \mathrm{E}$ to $92^{\circ} 20^{\prime}$ ) is a place of enormous interest and potential for ethno botanist.19 tribal community such as live harmoniously together within the district with several non tribal groups like the Bengali, Manipuri, etc. According to the Census, 2011 the total population of this state is $36,71,032$. Tripura has been subdivided into 8 districts (January, 2012) namely; North Tripura, West Tripura, South Tripura, Dhalai, Khowai, Unakoti, Sipahijala and Gomati. Most of the villages are situated far from modern conveniences and inaccessible by road or rail. Thus, the rural villagers have deep faith in their traditional healthcare system and in most of the cases prefer them to the modern system of medicine.

\section{Investigating methods}

Field investigations were conducted during the year 2013-2014 as per well planned schedule to collect information on medicinal plants used by the Manipuri community. Survey was done by standard procedure (Jain and Rao, 1977), through a questionnaire and group discussion with the community heads, old people, and women and also from neighboring market (Rao and Hajra, 1994) and cross checked. The interviews and discussions were carried out in the local language because the author is a native speaker of the language. The collected ethnobotanically important plant specimens were identified with the help of Flora of Tripura State (Deb, 1983).

\section{Results and discussion}

This present investigation documented 43 medicinal plants from 35 families (Table 1). The prominent families include Rutaceae (3 species); Acanthaceae, Amaryllidaceae, Apiaceae, Araceae, Lamiaceae, Zingiberaceae ( 2 species each) and rest of the families contain only 1 species each. Among the medicinal plants reported, the most common growth form was herbs $(55.81 \%)$ followed by trees $(30.99 \%)$ and shrubs (13.95\%) (Fig. 1). This study indicates that the people of the Manipuri community north district of Tripura have acquired considerable knowledge about the medicinal uses of plants in their surroundings, and in their daily life to remain healthy.

Different plant parts of these species, such as leaf, stem, bark, fruit, seed, root, rhizome, etc. were used in different forms for the management of various ailments as a curative agents (Figs. 2, 3 and 4). The drug used for different diseases are generally taken by orally. The time of taking, dose and duration of practice of these folk-medicines are varied on the basis of disease. Many of these plant species and their parts are used as vegetable, spice and fruit in daily life by the people of Tripura, which also provide nutrition, supply minerals and may confer beneficial effect to remain healthy. Unfortunately, there is lack of fruitful attempts to promote and conserve this immense treasure of traditional knowledge.

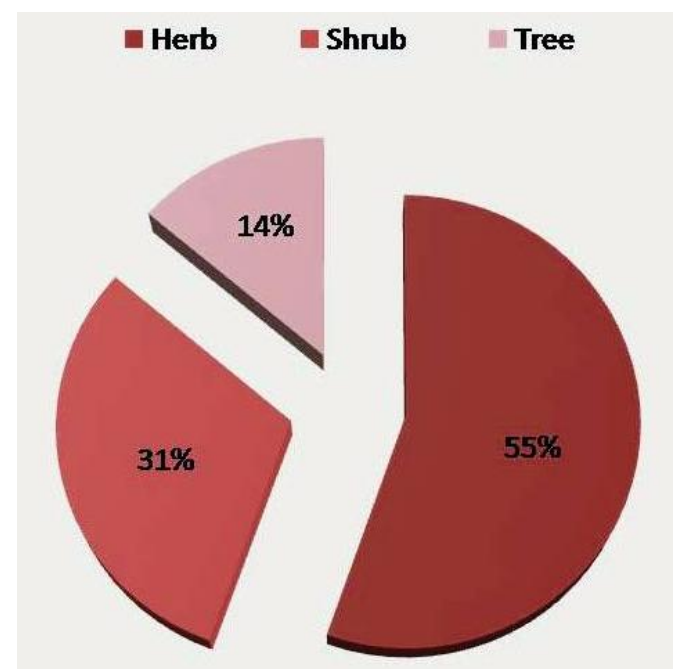

Fig. 1: Habits of documented ethnomedicinal plant species.

During the survey, it has been observed that the people of Manipuri community still believe on traditional herbal medicines up to great extent. Though pharmacological activities of several plants have been 
investigated and some of them are already incorporated in modern medicinal system based upon the traditional knowledge. During the course of this survey we also found that many of these traditional medicinal plants used by the Manipuri community are still a large unexploited source of structurally novel compounds that might serve as lead for the development of novel drugs and have great potential to be developed as standard preparation for different disorders. The establishment of community clinic may be helpful in changing gradually the existing pattern of indigenous knowledge based system of healthcare Therefore, some initiative should be taken up to perform phytochemical and pharmacological studies to support and validate the potential of local plants used in medicine.

Table 1. Enumeration of medicinal plants used for curing various human diseases by Manipuri community in North Tripura district.

\begin{tabular}{|c|c|c|c|c|c|}
\hline $\begin{array}{l}\text { Sl. } \\
\text { No. }\end{array}$ & Scientific name & Family & $\begin{array}{l}\text { Vernacular } \\
\text { name }\end{array}$ & Parts used & Ethnomedicinal uses \\
\hline 1 & Adhatoda vasica $\mathrm{L}$. & Acanthaceae & Nongmangkha & Fresh leaves & $\begin{array}{l}\text { Fresh leaves are used in Cough, cold, } \\
\text { dysentery and allergic problems }\end{array}$ \\
\hline 2 & $\begin{array}{l}\text { Aegle marmelos Correaex } \\
\text { Koen. }\end{array}$ & Rutaceae & heikakok & $\begin{array}{l}\text { Fresh leaves, } \\
\text { fruits }\end{array}$ & $\begin{array}{l}\text { Leaves are used for religious purposes. } \\
\text { Leaves are also used for curing } \\
\text { stomach disorder or loose motion. } \\
\text { Fruits are eaten raw and boiled as well. } \\
\text { Fruit pulp is used against stomach } \\
\text { disorder. }\end{array}$ \\
\hline 3 & Allium cepa $\mathrm{L}$. & Amaryllidaceae & Thilhau & Bulb & Bulb is useful in purifying blood. \\
\hline 4 & Allium sativum $\mathrm{L}$. & Amaryllidaceae & Chanam & Bulb & $\begin{array}{l}\text { Paste of the bulb is useful in lowering } \\
\text { the blood pressure. }\end{array}$ \\
\hline 5 & $\begin{array}{l}\text { Alocasia indica (Roxb.) } \\
\text { Schott. }\end{array}$ & Araceae & Yendem & Petiole & $\begin{array}{l}\text { Petiole Boiled with added ingredients } \\
\text { and taken for rejuvenating women } \\
\text { after giving birth }\end{array}$ \\
\hline 6 & $\begin{array}{l}\text { Alocasia macrorrhizos (L.) } \\
\text { G.Don. }\end{array}$ & Araceae & Hongoo & Corm & $\begin{array}{l}\text { Corm is used as a vegetable for } \\
\text { nursing mother and old men }\end{array}$ \\
\hline 7 & Aloe vera (L.) Burm.f. & Xanthorrhoeaceae & Ghritokumari & Fresh leaves & $\begin{array}{l}\text { Fresh leaf juice are useful in fever, } \\
\text { burn injury and stomach ache }\end{array}$ \\
\hline 8 & Alpinia galanga (L.) Willd. & Zingiberaceae & Kanghu & Rhizome & $\begin{array}{l}\text { Rhizome is useful in expel ling } \\
\text { intestinal worm and controlling high } \\
\text { blood pressure }\end{array}$ \\
\hline 9 & Azadirachta indica A. Juss. & Meliaceae & Neem & Fresh leaves & $\begin{array}{l}\text { Fresh leaves are consumed during } \\
\text { stomach problem, cough, cold, } \\
\text { pimples, fever, small pox, chicken } \\
\text { pox and worm }\end{array}$ \\
\hline 10 & Averrhoa carambola $\mathrm{L}$. & Oxalidaceae & Heiningjom & Fruit & $\begin{array}{l}\text { The fruit juice mixed with sugar is } \\
\text { used to cure jaundice .Fruits are also } \\
\text { useful in curing Burns and scalds }\end{array}$ \\
\hline 11 & Blumea balsamifera (L.) DC. & Asteraceae & Langthrei, & $\begin{array}{l}\text { Tender } \\
\text { shoots, fresh } \\
\text { leaves }\end{array}$ & $\begin{array}{l}\text { Tender shoots and fresh leaves are } \\
\text { useful for treating stomach ache }\end{array}$ \\
\hline 12 & Catharanthus roseus $\mathrm{L}$. & Apocynaceae & Darilei & Fresh leaves & $\begin{array}{l}\text { Fresh leaf juice is taken regularly in } \\
\text { diabetes; the fresh leaves of the plant } \\
\text { are crushed and applied on place of } \\
\text { insect bite and fresh wound. }\end{array}$ \\
\hline 13 & Carica papaya $\mathrm{L}$. & Caricaceae & Awathabi, & Fruits & $\begin{array}{l}\text { Fruits are used constipation. Fruits are } \\
\text { also used in insect and dog bites. }\end{array}$ \\
\hline 14 & Centella asiatica $\mathrm{L}$. & Apiaceae & Peruk, & Whole plants & $\begin{array}{l}\text { Whole plants useful for Irritation, } \\
\text { inflammation of throat and dysentery }\end{array}$ \\
\hline 15 & Chenopodium album $\mathrm{L}$. & Amaranthaceae & Monsaobi & Tender shoot & $\begin{array}{l}\text { Tender shoots are useful in treating } \\
\text { Leucorrhoea }\end{array}$ \\
\hline 16 & Citrus medica $\mathrm{L}$. & Rutaceae & Champra & Fruits & Fruits are used to cure obesity \\
\hline 17 & Citrus macroptera Montrouz. & Rutaceae & Haribob & Fruits & $\begin{array}{l}\text { Fruits are used in treating gall bladder } \\
\text { stone. }\end{array}$ \\
\hline 18 & $\begin{array}{l}\text { Clerodendrum viscosum } \\
\text { Ventenat }\end{array}$ & Verbenaceae & Kuthap & Fresh leaves & $\begin{array}{l}\text { Fresh leaf extract used as expectorant; } \\
\text { decoction used in high blood pressure. }\end{array}$ \\
\hline
\end{tabular}




\begin{tabular}{|c|c|c|c|c|c|}
\hline $\begin{array}{l}\text { Sl. } \\
\text { No. }\end{array}$ & Scientific name & Family & $\begin{array}{l}\text { Vernacular } \\
\text { name }\end{array}$ & Parts used & Ethnomedicinal uses \\
\hline 19 & $\begin{array}{l}\text { Cynodom dactylon (L.) } \\
\text { Persoon }\end{array}$ & Poaceae & Tingthow & Young twigs & $\begin{array}{l}\text { Root infusion in piles, crushed roots in } \\
\text { chronic gleets; plant juice astringent, } \\
\text { useful in cuts and wounds, }\end{array}$ \\
\hline 20 & Eryngium foetidum $L$. & Apiaceae & Awaphadigom & Whole plants & $\begin{array}{l}\text { Whole plant is used in the treatment of } \\
\text { hypertension, constipation, stomach } \\
\text { ache, worms and diarrhoea. }\end{array}$ \\
\hline 21 & Hibiscus rosa-sinensis L. & Malvaceae & Jaba kusum & $\begin{array}{l}\text { Leaves and } \\
\text { flowers }\end{array}$ & $\begin{array}{l}\text { Young flowers are taken in irregular } \\
\text { menstruation problem; flowers and } \\
\text { leaves are made into paste and applied } \\
\text { on hair in dandruff problem. Leaves } \\
\text { are also used in curing from irritation, } \\
\text { burn injuries and fever }\end{array}$ \\
\hline 22 & Houttuynia cordata Thunb. & Saururaceae & Toninghok & Whole plant & $\begin{array}{l}\text { Fresh whole plants are used in the } \\
\text { treatment allergy and tonic }\end{array}$ \\
\hline 23 & Ipomea aquatica Forsk. & Convolvulaceae & Komrek & Fresh leaves & $\begin{array}{l}\text { Paste of the leaves are useful for the } \\
\text { patient suffering from diabetes }\end{array}$ \\
\hline 24 & $\begin{array}{l}\text { Kalanchoe pinnata (Lam.) } \\
\text { Pers. }\end{array}$ & Crassulaceae & Hangaidakmana & Fresh leaves & $\begin{array}{l}\text { Crushed leaf is kept on wound/injury } \\
\text { to stop bleeding; fresh juice of the leaf } \\
\text { is taken in early morning in dysenteric } \\
\text { condition and kidney stone. }\end{array}$ \\
\hline 25 & Leucas aspera Spreng. & Lamiaceae & Lembum & Tender shoot & $\begin{array}{l}\text { Fresh tender shoot is used as a } \\
\text { vegetable and also useful in treating } \\
\text { the patient suffering from cough. }\end{array}$ \\
\hline 26 & Mimosa pudica $\mathrm{L}$. & Mimosaceae & Ikaithabi & Tender shoots & $\begin{array}{l}\text { Tender shoots are used in treating the } \\
\text { patients of Piles and jaundice. }\end{array}$ \\
\hline 27 & Momordica charantia $\mathrm{L}$ & Cucurbitaceae & Karanakhabi & Fruits & $\begin{array}{l}\text { Fruit juice is taken as a treatment of } \\
\text { viral fever and malaria. }\end{array}$ \\
\hline 28 & Moringa oleifera Lam. & Moringaceae & Sajna & Bark & $\begin{array}{l}\text { Bark paste is applied in toothache and } \\
\text { used to clean the teeth }\end{array}$ \\
\hline 29 & Musa paradisiaca Roxb. & Musaceae & Laphu & $\begin{array}{l}\text { Unripe or ripe } \\
\text { fruits, stems, }\end{array}$ & $\begin{array}{l}\text { Stems and unripe fruits are useful in } \\
\text { dysentery and diarrhoea. Ripe fruits } \\
\text { clearance of stomach. }\end{array}$ \\
\hline 30 & Nelumbo nucifera Gaertn. & Nelumbonaceae & Thambal & $\begin{array}{l}\text { Young leaves, } \\
\text { dried leaves, } \\
\text { seeds, roots }\end{array}$ & $\begin{array}{l}\text { Leaves are useful in diabetes, } \\
\text { diarrhoea, cholera, liver disfunction. } \\
\text { Seeds are used in cardiac complaints. } \\
\text { Roots are useful in piles bleeding. }\end{array}$ \\
\hline 31 & $\begin{array}{l}\text { Nymphaea rubra Roxb. ex } \\
\text { Andrews }\end{array}$ & Nymphaeaceae & Tharo angangba & Rhizomes & $\begin{array}{l}\text { Rhizomes are useful in treating the } \\
\text { patient suffering nose bleeding, piles, } \\
\text { dysentery and also function as cardio } \\
\text { tonic. }\end{array}$ \\
\hline 32 & Nyctanthes arbortristis L. & Oleaceae & Singarei & $\begin{array}{l}\text { Leaves and } \\
\text { flowers }\end{array}$ & $\begin{array}{l}\text { Leaves are blend into a paste using } \\
\text { mustered oil and applied in worm } \\
\text { infection externally; flowers are } \\
\text { crushed and applied to reduce } \\
\text { inflammation. }\end{array}$ \\
\hline 33 & Ocimum basilicum L. & Lamiaceae & Naosek-lei & $\begin{array}{l}\text { Fresh leaves } \\
\text { and tender } \\
\text { shoots }\end{array}$ & $\begin{array}{l}\text { Fresh leaves and young shoots are } \\
\text { used in treating fever. }\end{array}$ \\
\hline 34 & Ocimum sanctum $\mathrm{L}$. & Lamiaceae & Tulsi & $\begin{array}{l}\text { Fresh leaves } \\
\text { and tender } \\
\text { shoots }\end{array}$ & $\begin{array}{l}\text { Fresh leaves are useful in bronchitis, } \\
\text { stomach problem, fever, cough, cold } \\
\text { and congestion of lungs. }\end{array}$ \\
\hline 35 & Perkia javanica Lam. & Fabaceae & Yongchak & Fruits & $\begin{array}{l}\text { Fruits are as a part of their meal and } \\
\text { useful for stomach disorders. }\end{array}$ \\
\hline 36 & $\begin{array}{l}\text { Phlogacanthus thyrsiflorus } \\
\text { (Hardwicke) Mabberleys }\end{array}$ & Acanthaceae & Nongmangkha & Fresh leaves & $\begin{array}{l}\text { Vapour in hot water with Nyctanthes } \\
\text { abor-tristis and Clerodendron } \\
\text { viscosum is inhaled in rheumatism. }\end{array}$ \\
\hline 37 & Phyllanthus emblica L. & Euphorbiaceae & Haigu & Fruit & $\begin{array}{l}\text { Fruits are made into paste and applied } \\
\text { in hair to reduce hair fall. }\end{array}$ \\
\hline
\end{tabular}




\begin{tabular}{|c|c|c|c|c|c|}
\hline $\begin{array}{l}\text { Sl. } \\
\text { No. }\end{array}$ & Scientific name & Family & $\begin{array}{l}\text { Vernacular } \\
\text { name }\end{array}$ & Parts used & Ethnomedicinal uses \\
\hline 38 & $\begin{array}{l}\text { Polygonum posumbu Buch.- } \\
\text { Ham. ex D. Don }\end{array}$ & Polygonaceae & Fakpai & $\begin{array}{l}\text { Tender shoots } \\
\text { and fresh } \\
\text { leaves }\end{array}$ & $\begin{array}{l}\text { The juice of the tender shoot and the } \\
\text { fresh leaves are used to reduce heart } \\
\text { beat. }\end{array}$ \\
\hline 39 & Psidium guajava $\mathrm{L}$. & Myrtaceae & Pungdon & $\begin{array}{l}\text { Fruits and } \\
\text { leaves }\end{array}$ & $\begin{array}{l}\text { Juice of young leaf or raw leaf is taken } \\
\text { in empty stomach to reduce abdominal } \\
\text { pain and dysentery; paste of the leaf is } \\
\text { applied in gum to reduce tooth pain. } \\
\text { Fruits are also useful for the treatment } \\
\text { of dysentery. }\end{array}$ \\
\hline 40 & Sapindus trifoliatus L. & Sapindaceae & Kekru & Fruits & The fruit is used for treating asthma. \\
\hline 41 & Terminalia chebula Retzius & Combretaceae & Manahi & Dried fruits & $\begin{array}{l}\text { Powder of the fruit with honey is used } \\
\text { to reduce vomiting; dried fruit is kept } \\
\text { in water overnight and early morning } \\
\text { the water is taken in cough and } \\
\text { asthmatic condition; paste of the fruit } \\
\text { is used in stomach pain. }\end{array}$ \\
\hline 42 & Tamarindus indica Linn. & Caesalpiniaceae & Mangge & $\begin{array}{l}\text { Fruits, leaves } \\
\text { seeds and } \\
\text { flowers }\end{array}$ & $\begin{array}{l}\text { Both ripe and unripe fruits are used in } \\
\text { stomach disorders, general body pain, } \\
\text { jaundice, yellow fever, as blood tonic } \\
\text { and skin cleanser. Leaves are used as } \\
\text { fodder. Fried or cooked seeds are } \\
\text { taken as delicacy. }\end{array}$ \\
\hline 43 & Zingiber officinale Roscoe & Zingiberaceae & Shing & Rhizome & $\begin{array}{l}\text { Fresh juice of the rhizome is used in } \\
\text { cough and menstrual disorder. }\end{array}$ \\
\hline
\end{tabular}

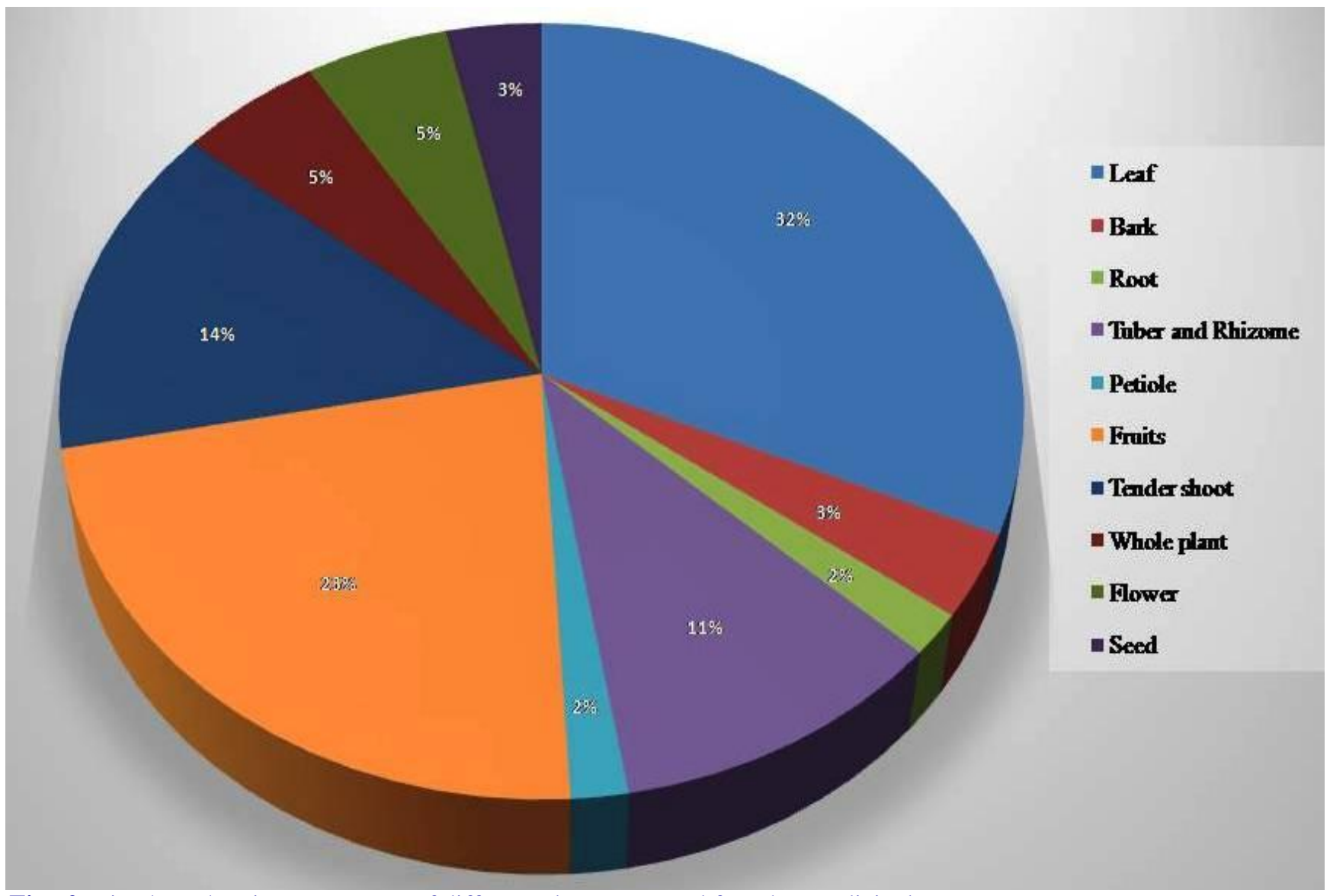

Fig. 2: Pie-chart showing percentage of different plant parts used for ethnomedicinal purposes. 


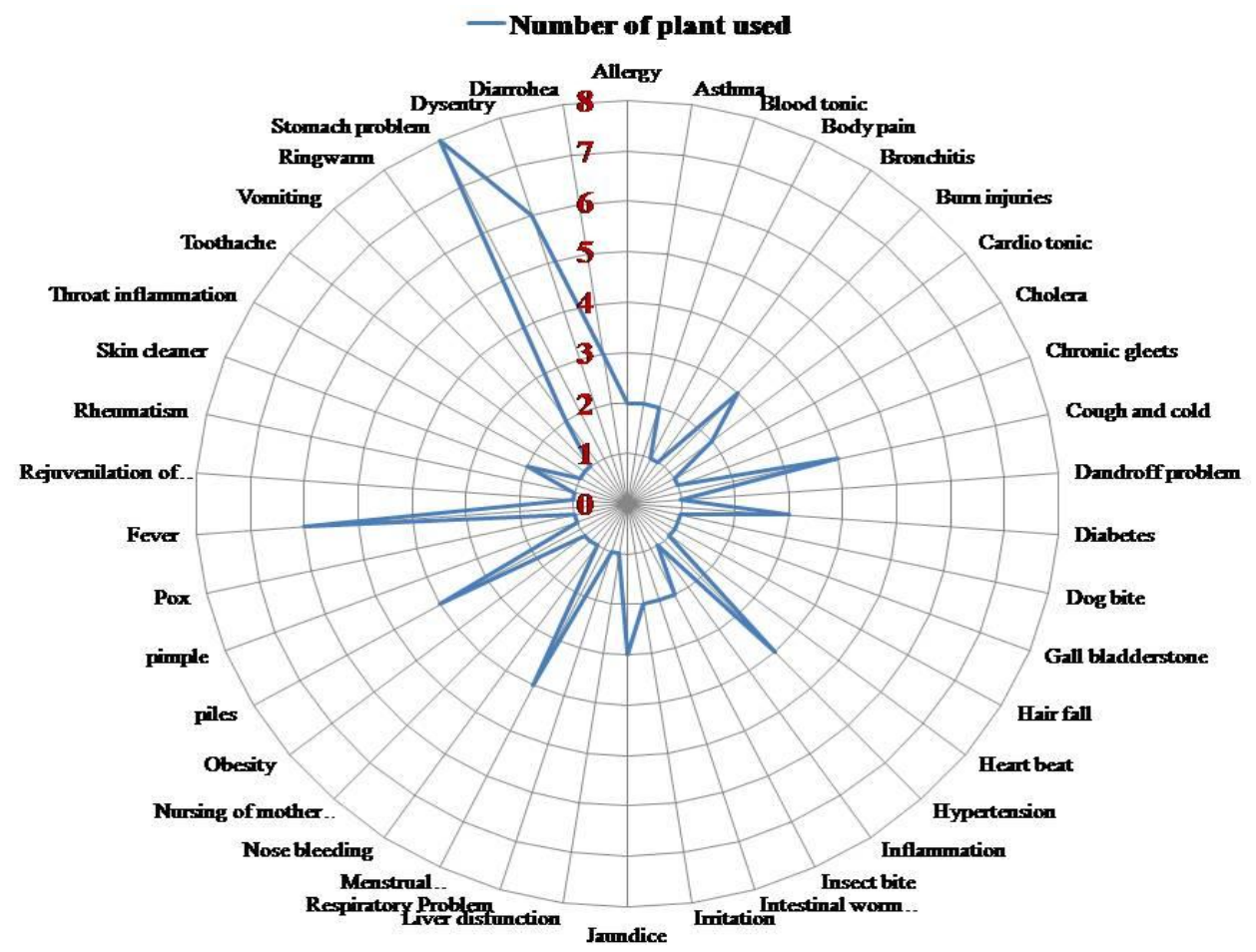

Fig. 3: Utilization of different ethno medicinal plant species used for human ailments by the Manipuri community of north Tripura district.

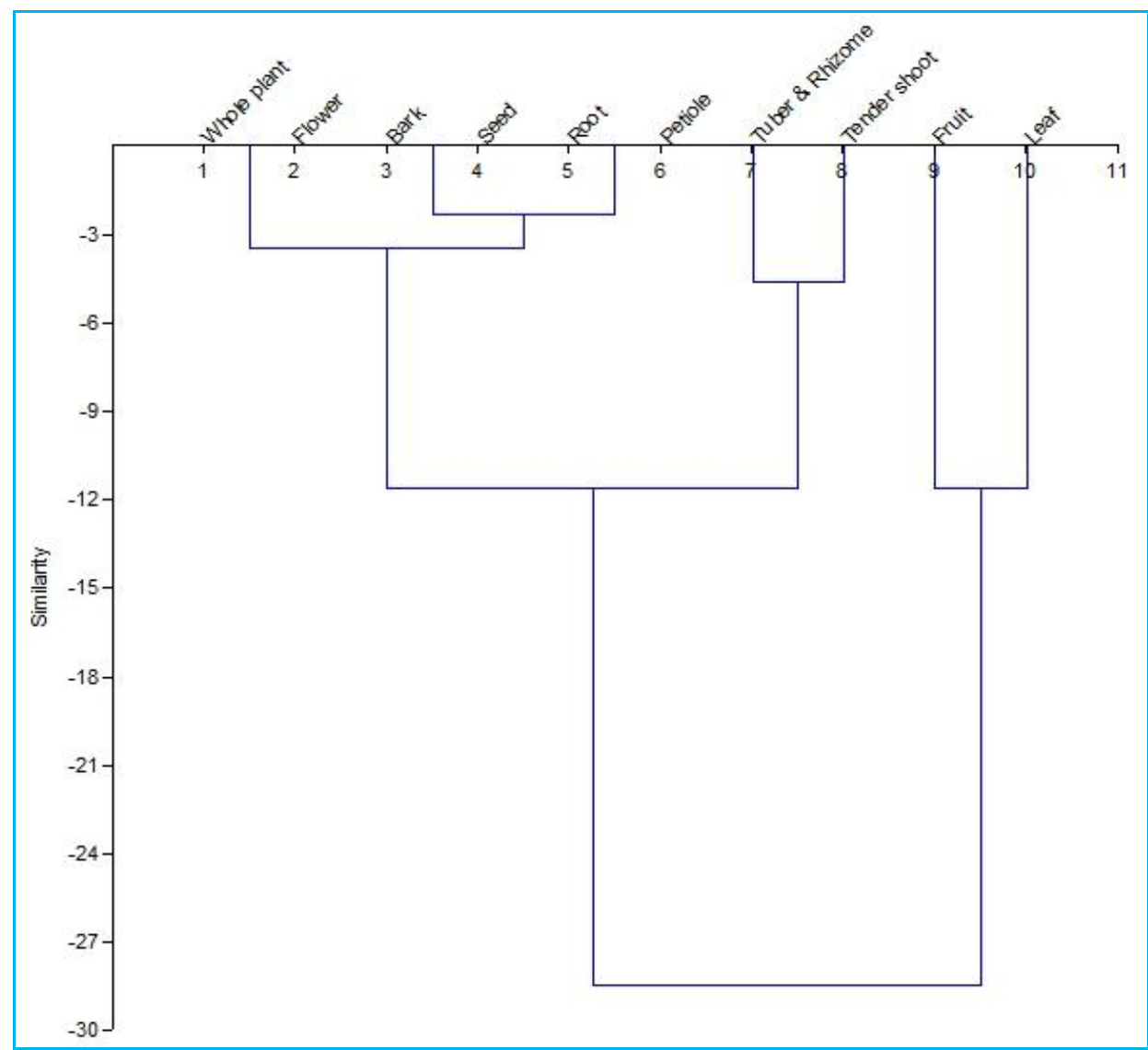

Fig. 4: Cluster analysis showing similarity between different plant parts used as a source of medicines by the Manipuri community. 


\section{Conclusion}

Tripura is rich source of plants and the existing tradition of treating different plants used as medicine by Manipuri community has been collected during the course of this present investigation. This community has their own medicine man called Maiba or Maibi who conduct different rituals for the prescription of these herbal medicines People living in rural areas still undergo these treatments this kind of knowledge is considered old-aged by the young peoples, who get influenced by the modern medicines, and the practices decline. Only a few individuals still carry on this knowledge for the future while the younger generation does not believe in it. Aggressive civilization, rapid growth of industrialization, excessive extraction of herbal raw material and pollution are an important reason for the loss of different species and cause danger to biodiversity. Preservation of medicinal plants and investigation on different plants are necessary, which can give better drug/formulation with fewer side effects in treatment of various diseases. Preservation of the indigenous knowledge of plants used in traditional health care is very important. Hence, it is the need of hour to create awareness among people on cultivation and conservation of phyto resources which are widely used for medicinal purposes.

\section{Conflict of interest statement}

Authors proclaim that they have no conflict of interest.

\section{Acknowledgement}

The authors are cordially grateful to the people of Manipuri community inhabiting in different localities of North district because of their kind support and cooperation during the field surveys. A lot of thanks to all the Maiba, traditional health practitioners and people involved in the interviews for providing information about the medicinal applications of the plants. The authors are also grateful to all the faculty members of the Botany Department, Govt. Degree College Dharmanagar for their constant support and encouragement.

\section{References}

Akerele, O.B.A., 1993. Nature's medicinal bounty: don't throw it away. World Health Forum. 14, 390-395.

Aniyam, C., 1995. Ecology and ethnomedicine: exploring links between current environmental crisis and indigenous medicinal practices. Social Sci. Med. 40, 321-329.
Azaizeh, H., Fulder, S., Khalil, K., Said, O., 2003. Ethnomedicinal knowledge of local herb practitioners in the Middle East Region. Fitoter. 74, 98-108.

Das, B., Talukdar Das, A., Dutta Choudhury, M., 2014. A few traditional medicinal plants used as antifertility agents by ethnic people of Tripura, India. Int. J. Pharma Pharmaceut. Sci. 6(3), 47-53.

Das, H.B., Majumdar, K., Datta, B.K., Ray, D., 2009. Ethnobotanical uses of some plants by Tripuri and Reang tribes of Tripura. Nat. Prod. Rad. 8, 172-180.

Das, S., Dutta Choudhury, M., 2010. Plants used against gastro-intestinal disorders and as anti hemorrhagic by three tribes of North Tripura District, Tripura, India. Ethnobot. Leaflet. 14, 467-478.

Das, S., Dutta Choudhury, M., 2012. Ethnomedicinal uses of some traditional medicinal plants found in Tripura, India. J. Med. Plants Res. 6(35), 4908-4914.

Deb, D.B., 1983. The Flora of Tripura State. Today and Tomorrows Printers and Publishers, New Delhi.

Farnsworth, N.R., Akerele, O., Bingal, A.S., Guo, A., 1985. Medicinal plants in therapy. Bull. World Health Org. 63, 965-981.

Ghorbani, A., Naghibi, F., Mosaddegh, M., 2006. Ethno botany, ethno pharmacology and drug discovery. J. Pharmaceut. Sci. 2, 109-118.

Jain, S.K., Rao, R, R., 1977. A Handbook of Field and Herbarium Methods. Today and Tomorrows Printers and Publishers, New Delhi.

Kuhnlein, H.V., O. Receveur, O., 1996. Dietary change and traditional food systems of indigenous peoples, Annual Rev. Nutr. 16, 417-442.

Majumdar, K., Datta, B.K., 2007. A study on ethnomedicinal uses of plants among the folklore herbalist and Tripuri medical practitioner: Part 2. Nat. Prod. Rad. 6, 66-73.

Majumdar, K., Saha, R., Datta, B.K., Bhakta, T., 2006. Medicinal plants prescribed by different tribal and nontribal medicine men of Tripura state. Ind. J. Trad. Knowl. $5,559-562$.

Martin, G.J., 1995a. Ethnobotany: A Method Manual. London, Chapman and Hall, UK.

Martin, P.H., 1995b. Commercialization of wild medicinal plants from South West Peubla. Mexico. Econ. Bot. 49, 197-206.

Martini-Bettolo, G. B., 1980. Present aspects of the use of plants in traditional medicine. J. Ethnopharmacol. 2, 5-7.

Peter, K.V., 2004. Introduction. In: Handbook of Herbs and Spices (Ed.: Peter, K.V.). Wood head Publishing Limited, Cambridge. pp.1-20.

Rao, R.R., Hajra, P.K., 1994. Methods of Research in Ethnobotany: A Manual of Ethnobotany. Scientific Publishers (India), Jodhpur.

Roy, M., Chakma, B., Datta, B.K., Gupta, A.K., 2010. Traditional knowledge of medicinal plants used by Chakma tribal community of Tripura, India. Pleione 4(1), 105-112. 
Salim, A.A, Chin, Y.W., Kinghorn, A.D., 2008. Drug discovery from plants. In: Bioactive Molecules and Medicinal Plants (Eds.: Ramawat, K.G., Merillon, J.M.). Springer, Berlin. pp.1-18.

Sandberg, F., Corrigan, D., 2001. Natural Remedies: Their Origins and Uses. Taylor \& Francis, New York. pp.1-4.

Sen ,S., Chakraborty, R., De, B., Devanna, N. , 2011. An ethnobotanical survey of medicinal plants used by ethnic people in West and South districtof Tripura, India. J. For. Res. 22,417-426.

Shanmugasundaram, R.V., Kalpana, D.P., Soris, T., Maruthupandian, A., Mohan, V.R., 2011. Ethnomedicinal legumes of southern Western Ghats, Tamil Nadu. J. Econ. Taxon. Bot. 35, 2.

Sharma, M.,C., Sharma, L., and Debbarma,J., 2014. Ethnobotnical studies of some plants used by tripuri tribe of Tripura, N.E. India with special reference to magico religious beliefs. Int. J. Plant Anim. Environ. Sci.4(3), 518-528.

Sheng-Ji, P., 2001. Ethnobotanical approaches of traditional medicine studies: some experiences from Asia, Pharmaceut. Biol. 39(1), 74-79.

Shil, S., Dutta Choudhury, M., 2009. Ethnomedicinal importance of Pteridophytes used by Reang tribe of Tripura, North East India. Ethnobot. Leaflet. 13, 634-643.

Singh, H.B., Hynniewta, T.M, Bora, P.J., 1997. Ethno medico botanical studies in Tripura, India. Ethnobot. 9, 56-58.

Umapriya, T., Rajendran, A., Aravindhan, V., Thomas, B., Maharajan, M., 2010. Traditional medication of Namakkal District, Tamil Nadu. J. Pharm. 4(3), 107-110.

\section{How to cite this article:}

Reshmi Singha, H., Chakraborty, K., Datta, A., 2016. An overview of medicinally important phyto resources used by the Manipuri community of North Tripura District of Tripura, North East India. Int. J. Curr. Res. Biosci. Plant Biol. 3(5), 46-53. doi: http://dx.doi.org/10.20546/ijcrbp.2016.305.007 